IRSH 5 I (2006), Supplement, pp. I I I-I4I DOI: I0.10I7/S002085900600263X

(C) 2006 Internationaal Instituut voor Sociale Geschiedenis

\title{
Mobility and Containment: The Voyages of South Asian Seamen, c.1900-I960*
}

\author{
Ravi Ahuja
}

\section{LASCARS IN A SEGMENTED LABOUR MARKET}

In the political and economic context of imperialism, the enormous nineteenth-century expansion of shipping within and beyond the Indian Ocean facilitated the development of a new and increasingly transcontinental regime of labour circulation. The Indian subcontinent, it is well known, emerged as a seemingly inexhaustible source for plantation, railway, and port labour in British colonies across the globe. Moreover, the new and predominantly seaborne "circulatory regime" itself relied to a considerable extent on the labour power of South Asian workers, on the lascar, as the maritime counterpart of the "coolie" labourer was called.

The number of Indian workers on the decks and in the engine rooms and saloons of merchant vessels grew considerably along with the rise of longdistance steam shipping in the last quarter of the nineteenth century. During the interwar years, on average about 50,000 South Asian seamen were employed on British merchant vessels alone and many thousands more by German and other European shipping companies. In this period, lascars made up roughly a quarter of all ratings on British merchant ships a proportion that remained fairly stable well into the i960s, despite the end of the colonial regime. ${ }^{2}$

\footnotetext{
* Research for this article was undertaken during a fellowship at the Centre for Modern Oriental Studies (Berlin) and funded by the German Research Council. I have greatly profited from the lively discussions of the Centre's Indian Ocean History Group (K. Bromber, J.-G. Deutsch, M. Frenz, F. Hartwig, P. Krajewski, and B. Reinwald). Earlier versions were presented at the 4th International Conference of the Association of Indian Labour Historians (Noida, March 2004), at the biennial conference of the German African Studies Association (VAD, Hanover, June 2004), and at the I8th European Conference on Modern South Asian Studies (Lund, July 2004). I am grateful for the critical comments and valuable suggestions received from many colleagues, especially from Gopalan Balachandran, Sabyasachi Bhattacharya, and Marcel van der Linden, though I do not wish to implicate any of them in my conclusions. The location of archival material is indicated by the following abbreviations: ILO (Archives of the International Labour Organization, Geneva); NAI (National Archives of India, New Delhi); NMML (Nehru Memorial Museum and Library, New Delhi); OIOC (Oriental and India Office Collections of the British Library, London); PRO (Public Record Office, London).

I. See Claude Markovits, Jacques Pouchepadass, and Sanjay Subrahmanyam (eds), Society and Circulation: Mobile People and Itinerant Cultures in South Asia 1750-1950 (Delhi, 2003), p. 3. 2. Laura Tabili, "We Ask for British Justice": Workers and Racial Difference in Late Imperial
} 
A sailor's work implies extraordinary mobility across territorial frontiers and cultural spheres. It is, therefore, tempting to conjure up images of a transcultural, uncontainable, and freely roaming proletariat of the seven seas. However, the social history of South Asian steamship workers sits rather uneasily with apologetic "globalization" narratives that celebrate unending beach parties of happy "hybridity" or revel in "the Dance of the Flows and the Fragments". 3 Nor does it corroborate Linebaugh and Rediker's hypothesis of an inclusive and revolutionary maritime work culture in the Atlantic of an earlier period. ${ }^{4}$ Instead, as Sherwood, Tabili, and others have shown, the maritime labour market of the nineteenth and twentieth centuries was structured into a rigidly racist hierarchy with South Asians at its bottom.'

This segmentation was no mere teething trouble of an emerging global labour market. Rather, in the course of its development, ethnic segmentation intensified and consolidated into a defining and permanent structural property of the maritime labour market. While wage differentials between European and South Asian seamen had apparently been volatile, moderate, and not always to the disadvantage of the latter in the seventeenth and eighteenth centuries, they became more marked and consistently defined in terms of a racist taxonomy in the early $1800{ }^{6}{ }^{6}$ By the mid-nineteenth century, lascars received as little as between one-fifth and one-third of the pay of European "able-bodied seamen" - a ratio that remained unchanged up to the 1980 s. $^{7}$

Britain (Ithaca, NY [etc.], I994), p. 47; Labour Gazette, X.2 (Bombay, October 1930), p. I 59; S.G. Sturmey, British Shipping and World Competition (London, 1962), p. 296; Gopalan Balachandran, "Circulation through Seafaring: Indian Seamen, I 890-1945", in Markovits et al., Society and Circulation, pp. 89-1 $30,98$.

3. The expression is from Fred Cooper's incisive critique of such trends: "What is the Concept of Globalization Good for? An African Historian's Perspective”, African Affairs, 100 (200I), pp. I89-213, I93. Such narratives unfortunately overshadow the newly invigorated field of Indian Ocean studies. This could, for instance, be witnessed at the largest recent international conference in this field, on "Cultural Exchange and Transformation in the Indian Ocean World" (UCLA, April 2002, conference volume forthcoming).

4. Peter Linebaugh and Marcus Rediker, The Many-Headed Hydra: The Hidden History of the Revolutionary Atlantic (London, 2002).

5. Marika Sherwood, "Race, Nationality and Employment among Lascar Seamen, I660 to I945", New Community, I7 (1991), pp. 229-244; Tabili, "We Ask for British Justice", pp. 4I-57. 6. Michael H. Fisher, Counterflows to Colonialism: Indian Travellers and Settlers in Britain I600-I857 (Delhi, 2004), pp. 34f., I 44.

7. OIOC, Bombay Marine Proceedings [hereafter, BoMP], IOR/P/6705, A223-224 (August I903); Reports from the Departmental Committee on Manning of Merchant Ships with Addenda and Statistical Tables (London, I 896), p. I 5; Dinkar Desai, Maritime Labour in India (Bombay, 1940), pp. 93-96; Lascar Diet Scale, OIOC, Economic \& Overseas Dept, Seamen, IOR/L/E/9/ 973 (1934-46); J.L. Mowat, Seafarers' Conditions in India and Pakistan (Geneva, I949), p. 57; Conrad Dixon, "Lascars: The Forgotten Seamen", in Rosemary Ommer and Gerald Panting (eds), Working Men Who Got Wet (Newfoundland, I 980), pp. 265-28 I, 278; Frank Broeze, "The Muscles of Empire - Indian Seamen and the Raj, I919-1939", Indian Economic and Social 
The segmentation of the maritime labour market thus displayed a remarkable stability. With regard to our present discussion, this implies that the seamen's extraordinary spatial mobility did not effect an equalization of their wages or other terms of contract. Hence the lascars' trans-territorial itinerancy did not, even in the long run, undermine the "barrier" that separated this ethnically defined segment of an occupational group from their better-paid European colleagues, and effectively prevented them from moving on to labour markets offering much higher wages in the various metropolitan cities they called at during their voyages. Statements of ship-owners, merchant navy officers, and colonial officials confirm these observations by pointing out time and again that an extremely low rate of desertion was among the principal advantages of replacing "white" and even Chinese seamen with lascars. ${ }^{8}$ Even in 1929, when an unusually large number of lascars jumped ship in British ports, the India Office registered no more than eighty desertions. In I93 I, the British government's efforts to introduce a more efficient scheme of preventing illegal immigration of Indian seamen met with a lukewarm response from the shipping companies, most of which stated that the problem was "trifling in extent". 9

As various studies have shown, the first traces of lascar settlement in Britain date back to the eighteenth century. In the mid-nineteenth century, South Asian seafarers contributed to the development of an "Oriental Quarter" in London and by the early twentieth century small communities of former Indian seamen, many of whom had jumped ship, sprang up in several British port cities. ${ }^{10}$ There is no point in questioning the qualitative importance of these early communities, as several of them were to turn into anchor points for chain migration - most famously in East London where a small group of lascars from Sylhet (today a district of Bangladesh bordering on the Indian state of Assam) grew over time into a large

History Review, I8 (198I), pp. 43-67, 44; R. Hope, A New History of British Shipping (London, I990), pp. 44I, 455; Tabili, "We Ask for British Justice", p. 45; G. Balachandran, "Recruitment and Control of Indian Seamen, Calcutta, I880-1935", International Journal of Maritime History, 9 (1997), pp. I-I 8, 2.

8. Dodwell-Castle Line (James Chambers \& Co., Liverpool) to Mercantile Marine Dept, Board of Trade, 28 August 1930, OIOC, Commercial \& Revenue Dept, IOR/L/E/7/I I25, file 2139; Graham's Trading Co. (Agents of Brocklebank's Cunard Service) to Secretary to Govt of Bengal, Maritime Dept, i I February i925, ibid.

9. High Commissioner for India [hereafter, HCI], General Dept, to Secretary to Government of India [hereafter, GoI], Commerce Dept, 26 November I93I, NAI, Dept of Commerce, Merchant Marine II, August 1932, file 67, M. II/32, s.nos. 6-8, part B, folios 3, I I.

I0. Rozina Visram, Ayahs, Lascars and Princes: The Story of Indians in Britain 1700-1947 (London, I986), pp. 34-59; idem, Asians in Britain: 400 Years of History (London, 2002), pp. 5769; Fisher, Counterflows to Colonialism, pp. 65-7I, I37-I79, 38I-392; Norma Myers, "The Black Poor of London: Initiatives of Eastern Seamen in the Eighteenth and Nineteenth Centuries", Immigrants \& Minorities, I3 (2-3) (1994), pp. 7-2 I. 
immigrant community. The same happened in other cases, such as that of firemen from the Mirpur area of Kashmir (today in Pakistan) who opened up avenues of immigration for many of their neighbours to northern England and the Midlands. ${ }^{\text {II }}$ However, whenever officials searched for the immigrant lascar before the I950s the figures they arrived at were hardly significant, despite the fact that tens of thousands of South Asian seamen had called at British ports every year since the last quarter of the previous century. ${ }^{\mathrm{I} 2}$

Moreover, the rise of the steamer, by rendering shipping more independent of the seasons, abbreviated the period during which lascars had to wait in British ports to embark on the return voyage to India, which apparently reduced their presence in Britain despite rapidly growing employment figures. ${ }^{\mathrm{I}}$ In the twentieth century, Indian seamen found themselves stranded in Britain in large numbers only at certain junctures, especially during the two World Wars. The more fortunate were readily employed by British factory owners, while others experienced the Empire's benevolence towards its colonial subjects in squalid detention camps. ${ }^{14}$ Nevertheless immigration into metropolitan capitalist countries by way of seafaring remained negligible in quantitative terms. No more than 8,000 Indians, it has been estimated, lived in Britain before the I950s. ${ }^{\text {Is }}$ Even if lascars made up a considerable share, this figure confirms the reports mentioned above that the rate of "desertion" of Indians from British merchant vessels was surprisingly moderate under the prevailing conditions of steep wage differentials.

Furthermore, though Indian seamen outnumbered all other non-British segments of the UK merchant marine's labour force, they appear to have been less likely to settle in British port cities. The Deputy Chief Constable of the Cardiff police thus estimated in 1929 that 200 Indian seafarers lived in this town as opposed to "some 6,000 Arabs, West Indians, Malays,

II. Katy Gardner, Global Migrants, Local Lives: Travel and Transformation in Rural Bangladesh (Oxford, 1995), pp. 34-65; Caroline Adams (ed.), Across Seven Seas and Thirteen Rivers: Life Stories of Pioneer Sylhetti Settlers in Britain (London, 1994), pp. 39-66; Yousuf Choudhury, The Roots and Tales of the Bangladeshi Settlers (Birmingham, I 993), pp. 69f.; Roger Ballard, "The Context and Consequences of Migration: Jullunder and Mirpur Compared", New Community, I I (I-2) (1983), pp. II7-136.

I2. A committee set up in I9I0 to investigate the problem of Indian and other colonial "destitutes" in Britain (and lascars settling in Britain were in official circles automatically assumed to be "destitutes") could, for instance, trace no more than 250 Indians for the period I 888 to I910; Visram, Asians in Britain, p. 69.

I3. For earlier problems of lascar accommodation during the winter season see Fisher, Counterflows to Colonialism, pp. $148-178$.

I4. Report of the Bombay Chamber of Commerce [hereafter, RBCC] I9I6 (Bombay, I917), pp. 55-56,329-335; Dinkar Desai, Among Indian Seamen in Great Britain (Bombay, I946); Adams, Across Seven Seas, pp. 46f.; Ballard, "The Context and Consequences of Migration", p. I25.

I5. Visram, Asians in Britain, pp. 254-269. 
Maltese and other seamen". ${ }^{16}$ If few lascars became immigrants, that was not because they had no one to turn to after jumping ship in a British port - several of the life accounts collected by Caroline Adams bring out clearly that the necessary links were firmly established before World War II and intending immigrants were well informed about where to find fellow countrymen (like the Sylheti Ayub Ali Master who ran a coffee shop in London's Commercial Road) who would help them to get a footing ashore. ${ }^{17}$ Yet, on the whole, South Asian maritime labour networks were not transformed into networks of large-scale migration before the i950s.

How do we explain the fact that only a small minority of Indian seamen climbed the barriers of wage discrimination? Why was the shipping industry never forced to level out maritime labour market disparities despite the lascars' high potential for mobility and increasing trade-union pressure? This article argues that the remarkable stability of these discrepancies was due to changing and interlocking sets of formal and informal institutional devices that may be called "scenarios of regulation". These "scenarios" are understood as the labour market's inherent structure, as its form of realization, and not in neoclassical terms of external intervention in this market. Various devices of these scenarios were aimed at restricting the lascars' freedom of movement. They were created in at least three overlapping spheres of regulation: British and "British Indian" maritime labour law, the immigration laws of metropolitan countries, and extra-legal structures of exclusion and containment. While each of these spheres of regulation by itself would have been unequal to the task, the combination of devices from all of them, it is argued, was fairly effective in controlling the mobility of Indian seamen and facilitated the reproduction of a segregated pool of poorly paid and legally inferior colonial labour in the international maritime labour market over more than a century. This article's concluding section briefly discusses the transformation of these scenarios of regulation after 1947 and sketches wider implications of these findings for research on ethnically segmented labour markets.

\section{MARITIME LABOUR LAW}

In the early years of the twentieth century, the British Board of Trade appointed a Mercantile Marine Committee to enquire into the causes and potential dangers of the dramatic increase in the employment of foreign, and especially lascar, seamen. The powerful British shipping industry

I6. E.W. Huddleston, Shipping Advisor of High Commissioner, 25 February I929, NAI, Dept of Commerce, Merchant Marine I, June 1929, file 45 I, M. I(8)/29, s.nos. I-5, part B, fo. 9 .

17. Adams, Across Seven Seas, pp. 39-45; Nawab Ali's account, ibid., pp. 73, 77; Haji Shirajul Islam's account, ibid., p. 98; Haji Kona Miah’s account, ibid., p. I33. 
defended, successfully as it turned out, their preference for Indian seamen against the criticism of the jingoistic Navy League and Havelock Wilson's seamen's union. The ship-owners' arguments were elaborated in a rambling pamphlet by one Captain W.H. Hood. He claimed that South Asian seamen rescued British merchant shipping from the "blight of insubordination" brought about by the employment of the English "Jack Tar", and in order to substantiate his assertion he quoted the following account by a shipmaster:

In a South African port three British steamers lay in dock side by side, one a transport with the usual British crew, the others manned respectively by lascars and Chinese. From the latter vessels not a man during their stay in port had been absent from his duties, while fully two-thirds of the transport's crew were being kept "unspotted from the world in the local gaol, serving sentences for continual drunkenness and absence without leave" ${ }^{18}$

Several statements of this sort could be cited. ${ }^{19}$ All of them fuse, of course, two constructs of the dominant social ideology of the time: first the image of the child-like "docile coolie", ${ }^{20}$ and secondly the idea of the morally immature "white proletarian". Yet even if shipmasters expressed their thoughts in terms of a well-established idiom of authoritarian paternalism, these thoughts are likely to have been informed by their experiences of quotidian social praxis. As for the "docility" of lascars on the shores of South Africa, consider, for instance, that until later than World War II employers could legally insert a clause into the special employment contracts of Indian seafarers, the so-called "lascar agreements", which in African and North American ports expressly denied them the customary right to shore leave. ${ }^{21}$ This permissible clause or "stipulation" had received the legal sanction of the colonial administration under pressure from the immigration policies of the USA and other states, something which will be discussed more fully in the next section. Consider also that the combined efforts of shipping industry and colonial administration prevented any formal regulation of the working hours of South Asian seamen throughout the same period. ${ }^{22}$ That meant not merely longer working hours, but practically unlimited control

I 8. W.H. Hood, Blight of Insubordination: The Lascar Question and Rights and Wrongs of the British Shipmaster (London, I903), p. 63.

I9. Relevant evidence has been presented at length in Ravi Ahuja, "Die 'Lenksamkeit' des 'Lascars'. Regulierungsszenarien eines transterritorialen Arbeitsmarktes in der ersten Hälfte des 20. Jahrhunderts", Geschichte und Gesellschaft, 3 I (2005), pp. 323-353.

20. See Kaushik Ghosh, "A Market for Aboriginality: Primitivism and Race Qualification in the Indentured Labour Market of Colonial India”, in G. Bhadra, G. Prakash, and S. Tharu (eds), Subaltern Studies X. Writings on South Asian History and Society (New Delhi, I999), pp. 8-48. 21. OIOC, Economic \& Overseas Dept Collections, Seamen, IOR/L/E/9/974; ibid., IOR/L/E/ 9/977, fol. 242 .

22. For the employers' arguments see RBCC 1921 , vol. I (Bombay, 1922), pp. I46-I47, and Fakirjee Cowasjee, Report on the I 3 th International Labour (Maritime) Conference, Geneva, 
over the person of the lascar, who risked being charged with breach of contract if he refused to be at the disposal of the shipmaster at any time, either when the ship was at sea or when it lay in port. ${ }^{23}$ It is therefore less useful to reduce the construct of the "docile lascar" to another element of a coherent "discourse" than to approach it as a peculiarly coloured and refracted reflection of practices of political and economic domination practices that need to be understood in their own right.

What needs to be emphasized here is that the word "lascar", which up to the early nineteenth century had been a general designation for seafarers from the whole Indian Ocean region, ${ }^{24}$ was slowly transformed into a legal category to distinguish lascars from "seamen" - the legal status of the former being different and markedly lower. ${ }^{25}$ In the early decades of the twentieth century, the question of who was a lascar time and again occupied government legal experts in England and India: lascars, most agreed, were seafarers resident in "British India". Since Aden was an important recruitment port and under the Government of Bombay, there was some consensus that Adenese seafarers too should be included. Yet many of them in fact came from Somalia, while one-third of all seamen

10-26 October 1929, NMML, M.A. Master Papers, IV, Printed Material, file 39. Hence, working hours were not regulated by law nor collective agreement but by custom, while overtime was not paid for. See Replies to Questions Relating to Hours of Work [...] [for International Labour Conference 1929], NMML, M.A. Master Papers, I. Subject Files, E. National Committees and Commissions, file 780; Replies furnished by the Indian Merchants' Chamber, Bombay to Questions Relating to Hours of Work and Organisation of Work on Board Ship, NAI, Dept of Commerce, Merchant Marine II, August 1929, file 465-M. I/29, s.nos. I-27, part A, p. 97; Memorandum on Regulation of Hours of Work of Indian Seamen (undated, probably i 944), NMML, M.A. Master Papers, I. Subject Files, F. International Committees and Commissions, file 896. According to an official statement in 1927, actual average weekly working hours were 6I hours for "deck lascars", 84 hours for sukhanis (helmsmen), 56 hours for "engine room lascars" and 63 to 70 hours for "saloon staff"; Shipping Master, Calcutta, to Government of Bengal [hereafter, GoBe], Marine Dept, I 4 June 1927, ibid., pp. 35-36.

23. Desai, Maritime Labour in India, pp. 65-72; A. Marr, Secretary to GoBe, to GoI, Commerce Dept, 23 June I92 I, OIOC, GoI Commerce Proc., IOR/P/i I 247, A7-ı; see also RBCC 192 I, vol. 2 (Bombay, I922), pp. 867-869; B.A. Malik, Memo on Regulation of Hours of Indian Seamen, I August 1945, NMML, M.A. Master Papers, subject file 896; GoI, Dept of Commerce, Memorandum on Wages, Hours of Work, Manning, 8 June I946, ibid., subject file 903, p. 4; R.K. Das, History of Indian Labour Legislation (Calcutta, I94I), pp. I $29 f$. See also references to the imprisonment of Indian seamen for refusing overtime work in Erich Kirchenknopf, "Bericht über die auf Veranlassung des Deutschen Verkehrsbundes angestellten Untersuchungen: I. Indische Seeleute an Bord deutscher Schiffe; 2. Indische Seeleute an Land”, Ms. (1929), Bundesarchiv, Stiftung Archiv der Parteien und Massenorganisationen der DDR (SAPMO), ZPA I $4 / 6 / 23$, pp. 55 f.

24. Janet Ewald, "Crossers of the Sea: Slaves, Freedmen, and Other Migrants in the Northwestern Indian Ocean, c. 1750-1914", American Historical Review, 105 (2000), pp. 6991, 75.

25. Leo Barnes, Evolution and Scope of Mercantile Marine Laws Relating to Seamen in India (Bombay, 1983), pp. 36-39; Sherwood, "Race, Nationality and Employment among Lascar Seamen", pp. $231-233$ and passim. 
recruited in Bombay were Indian Christians from the Portuguese colony of Goa. Moreover, could "Eurasians" ${ }^{26}$ be employed as lascars, and what kind of agreement applied to subjects of Indian princely states? Even more controversially, what was to be done about the sizeable community of Chinese seafarers resident in Calcutta at a time when a "yellow-peril" campaign in Britain targeted East Asian seamen ${ }^{27}$

The reason for such debates was that the freedom of movement of seafarers under "lascar agreements" was much more restricted than that of "white" seamen and subject to different regulations from those of other socalled "coloured seamen". Most importantly, lascar seamen could not be engaged for single journeys (from Bombay to London for instance), for "lascar agreements" were concluded either for a round-trip voyage or for a period of twenty-four months, and later twelve months. In any case, shipmasters could discharge lascars only in Indian ports, and South Asian seamen could in no circumstances terminate their contracts in any port outside "British India". ${ }^{28}$ That regulation ostensibly protected the lascar from being abandoned in a European port where, it was assumed, he would invariably become destitute and a burden to the respective municipality or British consulate. Shipping companies were accordingly held responsible for the repatriation of all lascars any master of one of their vessels might have left behind in any port outside India. ${ }^{29}$

Yet there are indications that Indian seamen did not necessarily appreciate that kind of "protection". Harsh conditions on a particular vessel, or the simple desire to sign on under "European articles" for much higher pay, were good reasons for claiming discharge on reaching a Western port. What was declared as the lascars' "privilege" was mainly in the interest of ship-owners who were, according to England's Merchant Shipping Act of 1894 and subsequent legislation, entitled to transfer even unwilling lascars to any vessel of their or any other company as long as it

26. "Eurasian", in colonial phraseology, was the designation for children of Indian mothers and European fathers.

27. For a summary of the relevant debates and legislation between I 888 and I920, see GoI, Dept of Commerce, to Government of Bombay [hereafter, GoBo], Marine Dept, Is September I920, OIOC, BoMP, IOR/P/I0793, A345f. See also RBCC 1904 (Bombay, I905), pp. I05-106, 498520; OIOC, Bengal Marine Proceedings [hereafter, BeMP], IOR/P/I0315 (I918), A $33-34$ (February I9I8), A3 (September I918); ibid., IOR/Pi I 178, A36 (March I922); OIOC, BoMP, IOR/P/7750, A355-360 (July 1907); ibid., IOR/P/7750, A503 (October 1907); ibid., IOR/P/ 9596, Ar7 (January 1915); ibid., IOR/P/10546, B42 (March I919); ibid., IOR/P/10793, A $347 f$ (November I920); ibid., IOR/P/I I008, A I8 I- I85 (I92 I); ibid., IOR/P/I I I88, A79-83 (I922); Engagement of Natives of India under Lascar Articles, OIOC, Dept Papers, Commercial \& Revenue Dept (I904-4I), IOR/L/E/7/48 I.

28. OIOC, Commercial \& Revenue Papers, IOR/L/E/7/853, file 7563 ; Desai, Maritime Labour in India, pp. 204-207; Tabili, "We Ask for British Justice", p. I 85.

29. Barnes, Evolution and Scope of Mercantile Marine Laws, pp. 168-178. See also Sherwood, "Race, Nationality and Employment among Lascar Seamen", pp. 230-232, 235. 
was bound for India. $3^{\circ}$ Hence an Indian seaman's only chance to terminate a contract outside South Asia was to break it, thereby committing the criminal offence of "desertion" and forfeiting all payments due from his employer.

That denial of the right to claim discharge restricted the room for manoeuvre available to Indian seamen in two ways. First of all, it reinforced the segmentation of the international maritime labour market by raising the barrier lascars had to surmount when they attempted to leave the low-pay and inferior-rights sector of the market, which was no doubt an ingenious method of reducing the freedom of movement of a potentially highly mobile occupational group. Second, any individual vessel was insulated from the wider world of maritime labour even when lying in port, which reinforced steep hierarchies on board ship hierarchies that could be contested less easily than on vessels with nonIndian crews. The lascar's (formal) freedom of contract was thereby reduced and so was his bargaining position, both in the labour market ashore and towards his superiors at sea. Maritime despotism (including the frequent application of physical violence) was even more attractive as a mode of managing the labour process when there was little risk that the crew would sign off at the next port and large demurrage fees build up before replacements could be found.

That might explain why representatives of conflicting interests held similar views regarding the nature of the lascars' labour relations. While W.H. Hood, the ship-owners' mouthpiece, rejoiced in 1903 that Indian seamen were "more completely the servants of the shipowner [...] than any other group of men doing similar work", ${ }^{3}$ the liberal trade unionist Dinkar Desai denounced the lascars' legal status in I94I as a "form of servitude". ${ }^{22}$ Desai made his remark a full decade after a new stipulation had been inserted into the "lascar agreements" by the Legislative Assembly, which gave an Indian seaman the right to claim discharge if he proved he could obtain employment in a higher grade, if he provided a substitute, created no additional costs for the owner, and on condition that the shipmaster gave his consent. ${ }^{33}$ Even this microscopic change had been opposed by the employers, for instance by the Bombay Chamber of Commerce, which had warned that a relaxation of the stipulations

30. See the various papers on "lascar agreements" in OIOC, Economic \& Overseas Dept Collections, Seamen, IOR/L/E/7/977. See also Reports from the Departmental Committee on Manning, p. Is.

31. Hood, Blight of Insubordination, p. 48.

32. Desai, Maritime Labour in India, pp. 204-208; see also R.N. Saksena, Seamen in India (Dehra Dun, I95I), pp. I02-104.

33. International Labour Organization, Monthly Report of the Indian Branch [hereafter, ILOrep] June I93 I, ILO C1903/3 I, pp. 62-63 (excerpt from Gazette of India, 23 May I93 I, part I, p. 4I 2). 
regulating the termination of agreements would "enable a seaman to break his contract [sic] on a very flimsy pretext and [...] cause intolerable inconvenience to the shipowner". ${ }^{34}$ Constraints on the lascars' freedom of movement by way of maritime labour law were thus defended tooth and nail.

\section{IMMIGRATION POLICIES}

When the SS City of Norwich arrived at New York in April I92 I the situation on board ship was extremely tense. ${ }^{35}$ The shipmaster had entered in his logbook a physical assault on a British engineer by a group of Indian stokers that included a foreman (tindal). Immediately after entering the port of Brooklyn two lascars jumped ship. Soon after, thirty-three Punjabi firemen, led by the engine-room serang, Fazel Ahammed, went ashore to lodge a protest against the behaviour of the shipmaster with the British Vice Consul and then with the agent of the Ellerman shipping line, the proprietors of the vessel. The master, they claimed, had broken the contractual obligation of providing warm clothing on the North Atlantic route. Moreover, they complained that the food rations were not in keeping with the agreement and that members of the crew had been maltreated. The incident gained some publicity when it was taken up by a New York lawyer of Indian origin named Henderson and one Alfred W. McCann, a journalist described by the British Consul General as "pronouncedly anti-British and strongly Sinn Fein". ${ }^{36}$

The thirty-three seamen went to court, but there are contradictory statements as to whether they tried to return on board ship and were denied access by the master, or themselves refused to take up their stations again. In any case, the shipmaster logged them as "deserters", hired a new crew, and put to sea. After almost a year, the US Circuit Court of Appeals reversed an earlier decision. The judges did not pronounce with regard to the seamen's allegations, although they opined that they seemed unfounded. Instead they focused on the question of whether the seamen had been wrongfully discharged by the shipmaster. They concluded that the lascars had had "no justification" for withdrawing from the ship; had therefore committed the crime of "desertion", and were to be punished under the provisions of England's Merchant Shipping Act of I 894 by forfeiture of wages and by imprisonment. ${ }^{37}$ We should recall here that

34. RBCC 1930, vol. I (Bombay, I93 I), pp. i88f.

35. This incident is documented in considerable detail in NAI, Dept of Commerce, Lascar Seamen, May i 922, s.nos. 94-95, filed.

36. Gloster Armstrong, British Consulate General, New York, to Principal Secretary for Foreign Affairs, I7 March 1922, ibid.

37. Fazel Ahammed et al. against SS City of Norwich, Opinion of United States Circuit Court of Appeals, for the Second Circuit, ibid. 
incarceration as a punishment for "desertion" or "absence without leave" was abolished for "white" seamen in the twentieth century but perpetuated for lascars by the Indian Merchant Shipping Act of 1923 well into the post-colonial period. $3^{8}$

The colonial records are silent as to what became of the thirty-three Punjabi firemen, but they include a clipping of one of McCann's articles. He reported that the lascars were "panic stricken" when the marshal suggested during the court's opening session that they should be brought to Ellis Island, which after World War I had been turned into an internment camp for unwanted immigrants: "Through an interpreter they said they knew all about this terrible place, and would not go there." All of them left the court building soon afterwards and we have no information about whether they managed to escape confinement and deportation. ${ }^{39}$ What the records clearly indicate is a considerable uneasiness among colonial administrators in India about the "Norwich incident". A Board of Trade official remarked: "This is a most unsatisfactory case. The charges may be vague $\&$ the facts obscure, but we know perfectly well that properly treated lascars would never desert at New York, with the threat of Ellis Island hanging on them." $4 \circ$ Another bureaucrat agreed that they "were not likely to desert in New York without very good cause". ${ }^{\mathrm{I}}$ The immigration policy of the United States was, in other words, a strong barrier under normal circumstances against a breakdown of ship's discipline and the absconding of a large part of the crew.

The case of the SS City of Norwich demonstrates how labour law and immigration policy combined in restricting the mobility of Indian seamen: the lascars committed not one but two offences when they left their ship. First, under British and "British Indian" maritime labour law, Indian (as opposed to "white") seamen had a legal claim neither to terminate their contract outside their home country nor take shore leave during their engagement. Leaving the ship without the shipmaster's consent, therefore, always amounted to "desertion" even when the crew took legal action against the master for breach of contract. Secondly, the immigration laws of the United States and of other countries ${ }^{42}$ further impinged upon the seamen's customary right to shore leave and made them liable to prosecution for the offence of "illegal entry" if they insisted on it.

38. Desai, Maritime Labour in India, pp. 204-208; Barnes, Evolution and Scope of Mercantile Marine Laws, pp. 175-176.

39. Alfred W. McCann, "Starved at Sea, Hindoos Assert", New York Globe, I6 May I 92 I.

40. Note by H.M. Lindsay, Commerce Dept, GoI, I 4 January 1922, NAI, Dept of Commerce, Lascar Seamen, May i 922, s.nos. 94-95, filed.

4I. Note by ? [illegible], Commerce Dept, GoI, I6 January 1922, ibid.

42. Lascars were, for instance, permitted to land in French ports only if they possessed "a certificate attesting that they would be engaged in a British port" (which was, as we have seen, contrary to British and "British Indian" maritime labour law); Desai, Maritime Labour in India, p. 6I. 


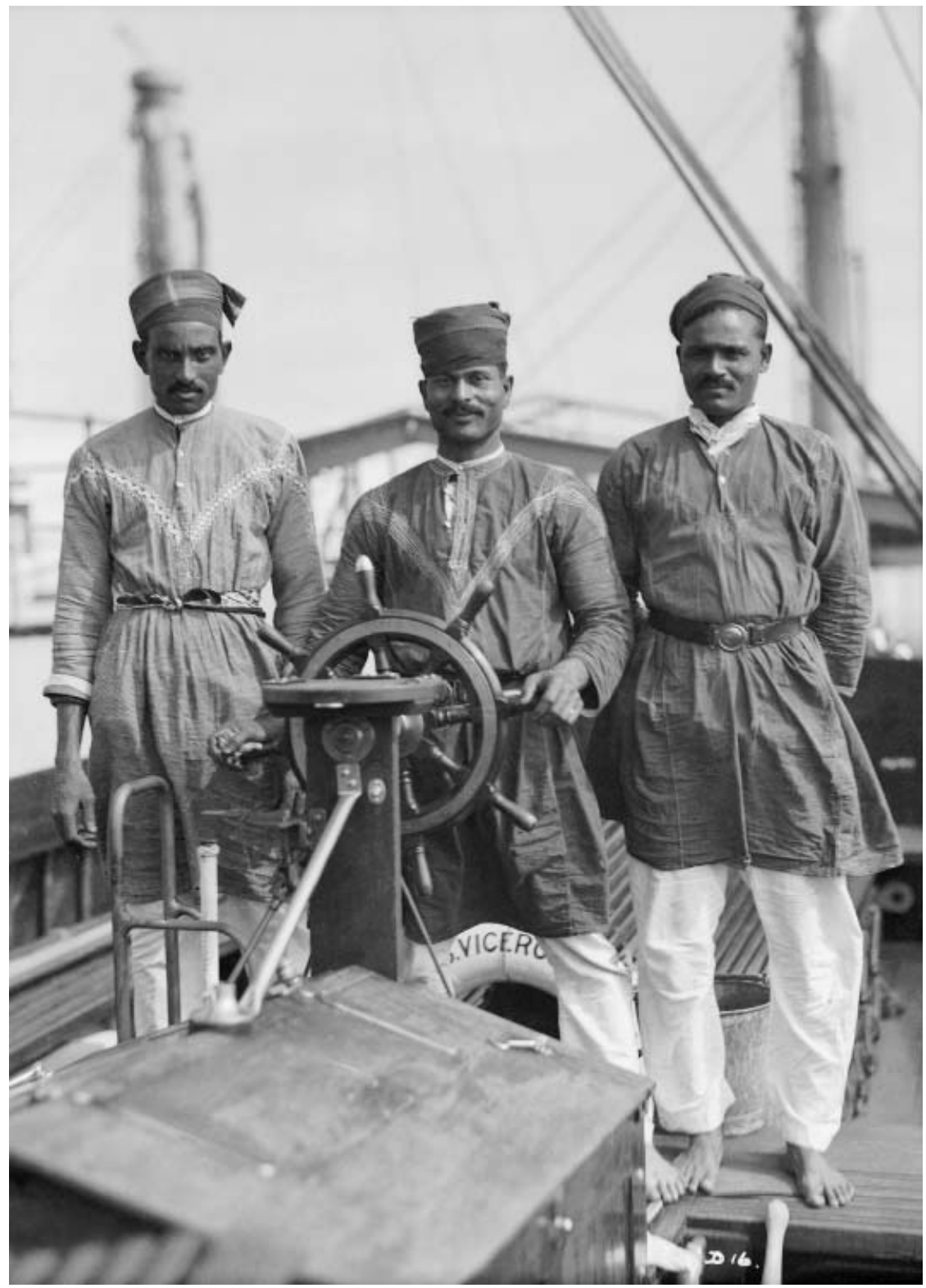

Figure I. Lascars on board the SS Viceroy of India (1929). This specimen of "official ship photography" shows Indian seamen on board ship, not in their usual working clothes, but in an orientalized dress uniform. The differentiation in the dress code of maritime workers according to their origin may be understood as a visualization of the legal as well as informal distinctions between the labour relations of lascars and (white) seamen.

National Maritime Museum Picture Library. Used with permission. 


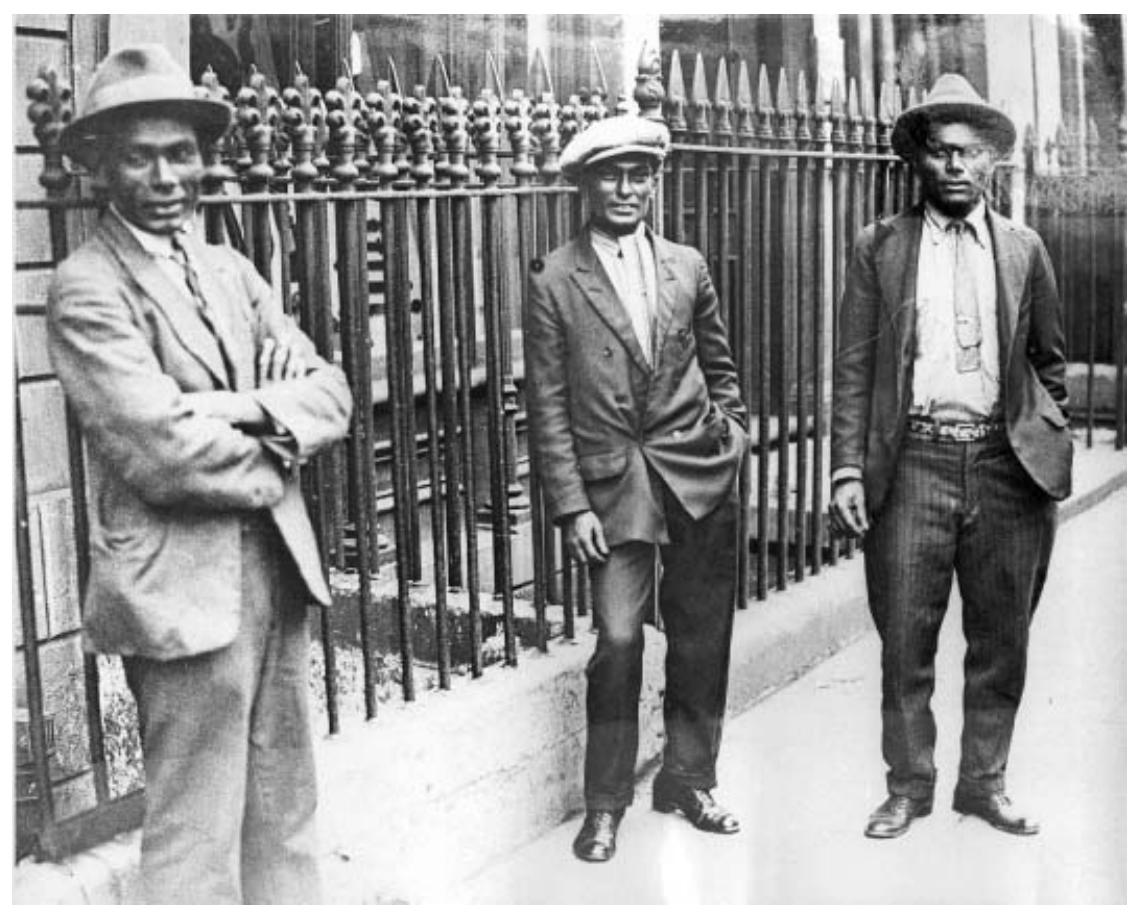

Figure 2. Seamen outside Dunbar House, West India Dock Road (I920s). The men on this photograph are apparently on land leave and outside the reach of ship discipline. Their choice of attire contrasts starkly with the supposedly oriental ship uniforms provided by the shipping companies (cf. Figure I).

Tower Hamlets Local History Library and Archives, Bancroft Library. Used with permission.

The first technique of regulation supplemented the economic subordination of labour by imposing an inferior legal status on the lascars and so created labour relations akin to those conceptualized in the English "master and servant law". 43 The second technique made it considerably more difficult to sidestep the barriers raised by the first and effectively protected shipmasters and shipping companies against indictments for breach of contract. As one colonial official remarked on the occasion of the Norwich case, "[so] far as the Indian Merchant Shipping Laws are concerned there does not seem to be any provision under these laws under which Govt. could bring an action against a master of a vessel guilty of an infringement on the terms of the agreement". ${ }^{44}$

In a period when the centre of the world economy shifted to North

43. See ibid., pp. 204-208. For a thorough discussion of the genealogy of "master and servant law" in the British Empire see Douglas Hay and Paul Craven (eds), Masters, Servants, and Magistrates in Britain and the Empire, I562-1955 (Chapel Hill, NC [etc.], 2004).

44. Note by Under-Secretary to the Commerce Department, GoI, I 2 January i922, NAI, Dept 
America and a growing share of merchant shipping was attracted to its ports, the immigration policies of the United States acquired an ever growing importance for South Asian maritime employment, despite the legal restrictions we shall turn to in the next section. More than 7,000 lascars entered North Atlantic ports of the USA during the summer months of 1937 on European vessels, 6,000 of them on British merchant ships. ${ }^{45}$ If Indian seaman were frequently denied land leave, that was due also to a US regulation introduced in the early I 920 s under which shipowners had to pay a security of \$500 for each lascar on board their ships, a sum that was withheld in case the lascar "deserted". ${ }^{46}$ This fine was raised to $\$ 1,000$ in the 1930 s, when a bill was introduced into the US Senate "authorising officials to board ships entering the United States' ports and remove or deport seamen of races ineligible for United States citizenship". British officials and employer representatives as well as the Indian nationalist press agreed that the purpose of these measures was not only to prevent Indian immigration but to protect the US domestic shipping industry against British competitors, which enjoyed a considerable advantage through their privileged access to cheap colonial labour from the Indian subcontinent. ${ }^{47}$

However, British settler colonies pursued similar policies. In I9021903, for instance, the Australian Federal Ministry persisted, against the criticism of the British Colonial Secretary, in giving a mail contract to the P\&O Company only on condition that lascars were not to be employed on mail steamers for Australia. The two reasons given for the policy were apparently to preserve the "purity of their race and to encourage the recruitment of British seamen". $4^{8}$

With regard to British immigration policy towards Indian seamen we can be very brief since the field has been explored thoroughly by several

of Commerce, Lascar Seamen, May 1922, s.nos. 94-95, filed. It is probably against this background that "facilities for making complaints" against the shipmaster were included in the Indian Merchant Shipping Act of 1923 , though their efficacy is rather doubtful. See P.G. Kanekar, Seamen in Bombay: Report of an Enquiry into the Conditions of Their Life and Work (Bombay, 1928), p. 35 .

45. ILOrep August 1939, ILO Ci903/r29, p. 42 (excerpt from The Bombay Chronicle, 27 August 1939).

46. Report of the Committee of the Bengal Chamber of Commerce 1922, vol. 2 (Calcutta, 1923), p. 332 .

47. OIOC, Economic \& Overseas Dept Collections, Seamen, IOR/L/E/9/974; ILOrep January 1932, ILO C1903/38, p. 59 (excerpt from The Leader, 27 January 1932); Jam-e-Jamshed, 26 January 1932, quoted in Government of Bombay, Native Newspaper Report [hereafter, BNNP] for the week ending 30 January 1932, p. 198.

48. Jam-e-Jamshed, 3 I July r 903 , quoted in $B N N P$, i August I903, p. I4. See also Praja Bandhu I 9 January 1902, quoted in ibid., 25 January 1902, pp. I2-I3; Rast Goftar, I7 May I903, quoted in ibid., 23 May 1903, p. 9; Gujarati, 2 I June, quoted in ibid., 27 June 1903, p. I2; Voice of India, I I July, quoted in ibid., I I July 1903, p. Io; Gujarati, 2 August 1903, and Mahratta, 2 August 1903, quoted in ibid., 8 August 1903, p. I5. 
historians, especially Marika Sherwood, Laura Tabili, Rozina Visram, and most recently by Gopalan Balachandran. While xenophobic campaigns against "coloured seamen" date back to the late nineteenth century, the economic downturn after World War I exacerbated hostility to immigrant workers. The number of non-European seamen who had found employment ashore had increased during the war and there were many more who competed with unemployed British sailors for engagements after peace had been concluded.

In I9I9 the Aliens Restriction (Amendment) Act required ship-owners to give preference to British seamen, while "destitute coloured seamen" were to be deported. The latter part of that regulation could not legally be applied to seamen from "British India" who were not "aliens" but "Imperial citizens" and had, therefore, the right to stay in Britain. In practice, however, Indian seamen were treated as "undesirable residents" and found it difficult to obtain work in British ports. ${ }^{49}$ Eventually the India Office decided to commission vessels at their own expense to transport lascars to ports in the Indian Empire if they agreed to repatriation on the promise of being paid a gratuity.

The official records do not convey the impression that those lascars who accepted the offer felt they had narrowly escaped "destitution" only thanks to an "act of grace" by the India Office - an image propagated by the contemporary British press..$^{\circ}$ Thus, when the Kurmark passed the Suez Canal in I92 I with I 50 "Adenese" and 63 Punjabi "destitute seamen" the situation on board was extremely tense. The Indian seamen insisted on land leave in Aden, on halal meat, and on the immediate payment by the India Office of the debts they had incurred with their creditors who were also on board. They were infuriated as they felt they had been cajoled into returning to India with false promises. The shipmaster pointed out that the port captain had told him he was "very sorry to oblige me to sail with such a crowd of Bolshevicks [sic] aboard". . $^{\text {I }}$

The regulation of I9I9 was consolidated by the infamous Coloured Alien Seamen Order of 1925 that forced "coloured" seamen to register themselves with the police when residing in Britain, and provided that they could be deported if they were deemed "destitute". Of the South Asian seamen, Goan Christians and subjects of princely states were immediately

49. Visram, Asians in Britain, pp. 196-224. See also Sherwood, "Race, Nationality and Employment among Lascar Seamen", pp. 234f.; Tabili, "We Ask for British Justice", pp. 33-36; Gopalan Balachandran, "Conflicts in the International Maritime Labour Market: British and Indian Seamen, Employers, and the State, I890-1939", Indian Economic and Social History Review, 39 (2002), pp. 71-100, 83f.; idem, "Circulation through Seafaring", pp. I I 3 f.

50. "Coloured Seamen Repatriated", The Western Mail (Cardiff), I 2 September I92 I; see also Visram, Asians in Britain, pp. 20I-205.

51. Shipmaster SS Kurmark to Director, India Office Shipping, 7 October 1921, OIOC, Commercial \& Revenue Papers, IOR/L/E/7/Iro3, fos 49-5 I; Resident, Aden to Secretary of State for India, I October I92 I (telegram), ibid., fos 74-75. 
affected by this regulation as they were not residents of "British India". However, more than a few lascars from areas of the subcontinent under direct British rule were deported under this Order since most could give no documentary proof of their origin. Many were, after all, ship-jumpers whose only proof of identity, the "Continuous Discharge Certificate", had stayed behind on the vessel where it was always kept in the shipmaster's cabin for as long as the agreement lasted. When they were issued with seamen's passports after registration, they were often categorized as "British protected persons", and not as Imperial subjects, which left them vulnerable to deportation. This government order was not revoked until 1943, when war had once again increased the demand for seamen. ${ }^{22}$

However, the efficiency of racist immigration and labour laws should not be overstated since there were many ways to subvert them. ${ }^{53}$ India Office officials pointed out, for instance, that "in some cases lascars who are deserters are smuggled in by boarding-house masters among Arab stoke-hold crews" in order to obtain engagements under European articles. ${ }^{54}$ Exceptionally well documented is the story of a steward named A.G. Straker who played on the vagueness of ethnic and national identification with considerable virtuosity to enlarge his room to manoeuvre on the maritime labour market. Hence, he sometimes claimed to be a resident of Britain and sometimes to be a "Eurasian" from India. In I923, an infuriated India Office bureaucrat noted that Straker "makes a business of travelling between India and the UK being constantly repatriated from one Country to the other". A number of officials made it a point to hunt him down and eventually identified him as a native of Jamaica. Imperial law could constrain the mobility of seamen but never control it totally. 55 Yet immigration policy set limits on the ingenious appropriation by "coloured" seamen of the opportunities offered them in an increasingly global maritime labour market. Their situation might have been similar to that of Hašek's good soldier Švejk, who could subvert the authority of his superiors but could not end the war.

\section{COMPETING LABOUR NETWORKS}

Extra-legal mechanisms were no less important than labour and immigration laws in the regulation of maritime labour relations in general and of

52. Tabili, "We Ask for British Justice", pp. I I3-I 34; Tony Lane, "The Political Imperatives of Bureaucracy and Empire: The Case of the Coloured Alien Seamen Order, I925", Immigrants \& Minorities, I3 (2-3) (1994), pp. I04-I29. See also Balachandran, "Conflicts in the International Maritime Labour Market”, pp. 83 f.

53. See Tabili, "We Ask for British Justice", pp. I $28 f$.

54. Summary of letter from High Commissioner for India, 26 November 193 I, NAI, Dept of Commerce, Merchant Marine II, August 1932, file 67, M. II/32, s.nos. I-I I, part B.

55. OIOC, Commercial \& Revenue Papers, IOR/L/E/7/1 165, file 3594. 
the seamen's mobility in particular. Elsewhere I have discussed at length the "networks of subordination" involving various middlemen and institutions through which shipping agents recruited and shipmasters controlled the lascars - networks that were simultaneously appropriated as "networks of the subordinated" for purposes at variance with employer interests. ${ }^{.6}$

With regard to mobility, this latter aspect of "subaltern" appropriation has been brought out clearly by scholars who have looked at the origins of lascar settlement in Britain. Immigrant Indians, often former seamen or boatswains themselves, founded boarding houses in British port towns that attracted ship-jumpers and provided them not only with accommodation but often also with jobs - by the I930s not infrequently in one of the mushrooming Indian restaurants. ${ }^{57}$ South Asian maritime labour networks also expanded into the British mainland in the form of pedlar rings which sold artificial silk shawls and cheap household goods from door to door, ${ }^{8}$ and we have already mentioned that maritime labour networks were transformed into networks of large-scale migration in the I950s and I960s. However, in combination with various legal regulations, the same networks that were able to integrate, connect, and facilitate mobility also had the capacity to exclude, insulate, and constrain the freedom of movement of seamen. It is to these legal regulations that we shall now turn.

Various regulations sanctioned by the Government of India since I 887 limited the geographical space in which Indian seamen could legally be employed. From I 893 onwards, lascars could be engaged only for voyages between the latitudes $60^{\circ} \mathrm{N}$ and $50^{\circ} \mathrm{S}$ during the winter months between October and March. Moreover, the engagement of Indian seamen on voyages in this season to all American North Atlantic ports beyond $38^{\circ} \mathrm{N}$, namely Boston and New York, and to the Baltic, was ruled out too. Such a piece of protective legislative racism was based on the assumption that "Asiatics" could not stand cold weather as well as the hardy Jack Tar. The "lascar line" was another type of legal constraint on Indian seamen's mobility excluding them, in effect, from some of the most important routes of world shipping. This regulation remained a binding clause in the

56. Ravi Ahuja, "Networks of Subordination - Networks of the Subordinated: The Case of South Asian Maritime Labour under British Imperialism (c.1890-1947)", in Harald Fischer-Tiné and Ashwini Tambe (eds), Spaces of Disorder: The Limits of British Colonial Control in South Asia and the Indian Ocean (forthcoming).

57. Adams, Across Seven Seas, pp. 39-52; Choudhury, The Roots and Tales, pp. 71-75. See also Tabili, "We Ask for British Justice", p. I43.

58. Letter from Geo. Smith \& Sons, Agents for Ellerman's City Line, i7 September 1925, NAI, Dept of Commerce, Shipping, September 1926, file 606-S, s.nos. I-I 8, part A, p. 22; Summary of letter from High Commissioner for India, 26 November I93 I, NAI, Dept of Commerce, Merchant Marine II, August 1932, file 67, M. II/32, s.nos. I-I I, part B. See also Balachandran, "Conflicts in the International Maritime Labour Market", pp. 85-87; idem, "Circulation through Seafaring”, pp. I I7-I 20. 
prescribed forms of "lascar agreements" for decades, and was only briefly relaxed during World War I when the demand for merchant seamen reached unknown heights. 59

Between the World Wars, the British shipping industry (and later the emerging Indian seamen's trade unions) persistently demanded the abolition of this clause, arguing that lascars had shown their ability during the war to bear the harsh climatic conditions of a North Atlantic passage and that improved conditions on steamships had made such voyages less demanding. ${ }^{60}$ In August 1938 the Government of India suspended the regulation experimentally for a period of three years. ${ }^{6 \mathrm{I}}$ When the experiment was reviewed a year later, it was reported that the returned seamen's state of health was "satisfactory". Moreover, it was emphasized that no European seaman had lost his job because of the clause's suspension: "Inquiries made at the Government Shipping Office, Bombay, reveal that the only persons hit by the decision are Malayan and Chinese deck hands [...]."62 That was apparently not considered a problem and had, in fact, been one of the explicit objectives British shipping companies had been pursuing with their demand to abolish the clause. "[O]n account of extensive smuggling of opium, and desertions of Chinese, we are considering the advisability of changing to Lascars", wrote executives of the Dodwell-Castle Line, ${ }^{63}$ while the agents of Brocklebank's Cunard Line observed that

[...] it has been found that both the Chinese and Malay crews are very liable to desert on arriving in the USA, thus causing a considerable loss to the owners of the line. It has also been our experience that Malay and Chinese crews are not as efficient as lascars on steamers trading from Calcutta to America in addition to which the former invariably give more trouble to the masters of our vessels. ${ }^{64}$

59. GoI, Dept of Commerce and Industry, to GoBo, Marine Dept, I 2 February 1920, OIOC, BoMP, IOR/P/10793, A 73-75.

60. NAI, Dept of Commerce, Merchant Marine II, September 1938, F. No. I I, M. II (2)/37, s.nos. I-9, part A. See also ILOrep January 1933, ILO, Ci 903/50, p. 67 (report about a meeting of the members of the Deck Department of the National Seamen's Union of India, Bombay, 20 December 1932); Labour Gazette (Bombay), XVI.ı (June 1937), p. 764 (report on All-India Seamen's Conference). For a view in favour of continued spatial exclusion of lascars, see Labour Gazette (Bombay), XIV.4 (December 1934), p. 285 (statement of Imperial Merchant Service Guild). See also Balachandran, "Conflicts in the International Maritime Labour Market", pp. 96-98.

6r. ILOrep August 1938, ILO, Cig03/117, pp. 41-42 (excerpt from Hindustan Times, 25 August 1938).

62. ILOrep June 1939, ILO, Cigo3/r 27, p. 42 (excerpt from The Times of India, I June 1939). 63. Dodwell-Castle Line (James Chambers \& Co., Liverpool) to Mercantile Marine Dept, Board of Trade, 28 August 1930, OIOC, Commercial \& Revenue Department Papers, IOR/L/ E/7/I I 25, File 2 I 39: Lascars, employment outside winter limits, main file (I 920-I 93 I). See also Andrew Weir \& Co., London and Glasgow, to Captain Darvell, Shipping Master, Calcutta, Io February 1925 , ibid.

64. Graham's Trading Co. (Agents of Brocklebank’s Cunard Service) to GoBe, Maritime Dept, 
The suspension of geographical prohibitions on lascar employment thus enabled employers to shift from Asian maritime labour networks they found less amenable, to those of the lascars. From another perspective, the abolition of legal restrictions did not entail a "de-regulation" enabling all maritime workers, as so many atomistic individuals, access to the labour market irrespective of socio-economic bonds. Access was regulated mainly by complex, predominantly extra-legal and non-public maritime labour networks which connected shipping agents, like the famous Mackinnon Mackenzie Company, and colonial port officials in Bombay and Calcutta with "licensed shipping brokers" and other recruitment agents (ghat serangs), and with trade unions and village clubs, with boarding-house keepers and moneylenders, village elders, and so-called serangs, who were the equivalents of British boatswains. In this case, the National Seamen's Union of India (which may be conceived of as a publicly operating and institutionalized element of the Bombay network and whose traces can be located more easily) urged the colonial government "to move shipping companies to engage Indian, rather than Malay and Chinese, seamen" on ships bound for North America. ${ }^{65}$ In this case, an Indian labour network responded to labour market competition by attempting to reduce the transterritorial movements of Malay and Chinese colleagues. In other words, not only did it manage to link itself to the North Atlantic maritime labour market, it contributed to the exclusion of competing Asian networks.

That was no isolated case - the networks of Indian seamen, like other labour networks under capitalism, ${ }^{66}$ were not mechanisms solely of incorporation. While they opened up avenues of trans-territorial mobility for some, they contributed to blocking them for others. Competition in the international maritime labour market was discernible not only between British and Indian seamen, but also between various maritime networks of the Indian Ocean region and even within South Asia. Hence, not all traditionally seafaring communities of coastal India gained access to the market for steamship labour - the south-eastern shores of India were heavily under-represented, while interior regions with little reputation for seamanship like Northern Punjab acquired some prominence. In the late nineteenth century, Punjabis and Pashtuns appear to have more or less driven out the Zanzibari "Sidis" from the engine rooms of British steamships, where the latter had so far been favoured as stokers. ${ }^{67} \mathrm{By}$

I I February 1925, ibid; see also Graham \& Co. to GoBe, Maritime Dept, is March i9 I 5 , OIOC, BoMP, IOR/P/I0793, A 75-76.

65. ILOrep January 1933, ILO, Ci $1903 / 50$, p. 67 (report about a meeting of the members of the Deck Department of the National Seamen's Union of India, Bombay, 20 December 1932).

66. See Eric Wolf, "Incorporation and Identity in the Making of the Modern World", in idem, Pathways of Power: Building an Anthropology of the Modern World (Berkeley, CA [etc.], 2001), pp. 353-369, 366-368.

67. Hood, Blight of Insubordination, p. I I see also Hope, A New History of British Shipping, p. 324; Ewald, "Crossers of the Sea", pp. 83 f. 
this time, thousands of Indian lascars were shipped as passengers to various ports of the Indian Ocean region, where they were engaged on steamships in preference to local labour. ${ }^{68}$ Abdul Majid, however, a ghat serang from Sylhet, met with little success in the I920s and I930s when he tried to convince the colonial authorities in Singapore that Chinese seamen should be replaced by "loyal British subjects" from Bengal and Malaya. ${ }^{69}$ During World War II, the Indian Seamen's Union (Calcutta) endorsed the replacement of 2,000 striking Chinese seamen by lascars, in $1942 .{ }^{70}$

There was also stiff competition between the labour networks of the two main recruitment ports for steamship labour in India, Calcutta and Bombay. Shipping companies had established permanent links with labour networks rooted in specific localities: P\&O preferred Muslim stokers from particular areas of northern Punjab, deck-hands from certain coastal villages in Gujarat or Ratnagiri, and Catholic stewards from the velhas conquistas, the "old conquest" areas of coastal Goa; the Clan, British India, and other steam navigation companies favoured firemen from the "seamen's zone" of central Sylhet; others hired Maldivians as deckhands whenever possible. ${ }^{71}$

Yet there was a permanent wage differential - Calcutta lascars received lower wages, and even the food rations their agreements entitled them to were smaller and less expensive - a discrepancy legitimized with bizarre anthropological arguments. ${ }^{72}$ In 1929, the Bombay-based Indian Seamen's Union demanded prohibition of the practice among shipping companies of

68. R.H.H. Hopkins, Shipping Master Bombay, to Bombay Marine Department, 2 December I9I3, OIOC, BoMP, IOR/P/9596, A309. See also Report by the Shipping Master Calcutta, I7 August 1918, ibid., IOR/P/i 1008, A 207.

69. Indian Employment Bureau, M.A. Majid, Singapore, to J. Foley, Under-Secretary to Board of Trade, Mercantile Marine, 2 September 1938, PRO, CO273/639/9, fol. I I-I 5 .

70. Indian Seamen's Union, Resolution on the Pending Grievances of the Indian Seamen, 3 I August 1943, NMML, M.A. Master Papers, I. Subject Files, A. Scindia Steam Navigation Company, file iso.

7r. OIOC, BoMP IOR/P/9083 (September I9I2), A347; W.A. Cosgrave, Off. Deputy Commissioner Sylhet, to Commissioner Surma Valley and Hill Districts, 21 August I9I3, OIOC, Commercial \& Revenue Papers IOR/L/E/7/696, file 405; Shipping Master Bombay to GoBo, Is January I918, OIOC, BoMP IOR/P/I0326, Bi9; Shipping Master Bombay to Bombay Marine Dept, Io March I920, OIOC, BoMP IOR/P/I0793, Aı60; Reply to the Report of the Seamen's Recruitment Committee (Clow Committee), August I923, OIOC, BeMP IOR/ P/I I 3 I2, A4I, p. 58, 65; Kanekar, Seamen in Bombay, pp. 5- 18; GoBo, Conditions of Industrial Labour in the Bombay Presidency, Royal Commission on Labour in India: Evidence (London, I93 I) [hereafter, RCLI Evidence], vol. I, part I (Bombay, Written Evidence), p. I49; written statement by Bombay Seamen's Union, ibid., pp. 293f; written statement by Mackinnon, Mackenzie \& Co., ibid., pp. 544f; Olga Esther Baptista, "The 'Coor' System - A Study of Goan Club Life" (M.A., University of Bombay, I958), pp. 89, 175; Choudhury, The Roots and Tales, pp. $58 \mathrm{f}$.

72. Desai, Maritime Labour in India, pp. 47f.; Saksena, Seamen in India, pp. 66f.; OIOC, BoMP IOR/P/6705, A299 (October 1903); OIOC, Economic \& Overseas Department Collections, Seamen (I925-I94I), IOR/L/E/9/973. 
"importing” crews from Calcutta, which had triggered violent clashes between seamen of the two ports. ${ }^{73}$ Conversely, in the early I930s, a breakaway union of Bengali Muslim stewards, led by the conservative Muslim League politician and future Pakistani prime minister H.S. Suhrawardy, tried to exclude Goan saloon crews from the Calcutta labour market. ${ }^{74}$ The demand to remove wage differentials was voiced somewhat more insistently only after non-particularistic trade-union policies gained some influence and trade-union links between the two ports intensified in the 1930 s. $^{75}$

Yet as late as 1948, the president of the National Seamen's Union, the largest of Bombay's seafarers' organizations at the time, "maintained that there should be separate unions for the ports of Bombay and Calcutta because conditions in the two ports were so dissimilar", giving weight to his opinion by drawing attention to divergent ethnic and religious affiliations: "while the saloon staff in Bombay are almost entirely Goan Christians, in Calcutta the saloon staff are predominantly Muslims". ${ }^{76}$ The union represented by this spokesman was by no means "communalistic" or exclusivist along ethnic lines; several of its key leaders, including the president himself, were, for instance, Muslims, though large parts of its membership were not. Their attitude rather reflected the competition between maritime labour networks based in distinct social spaces - a particularism of locality that was sometimes given plausibility by appealing to the ethnicized common sense of the time.

Of all maritime labour networks, that of the Goan stewards was surely the best organized - the power of outside recruitment agents, moneylenders, and commercial boarding-house keepers had been limited by cooperative village clubs, the kur, of which about 300 existed in Bombay in the I 920 s and several in Calcutta and Karachi. The kurs had been created since the mid-nineteenth century by communidades of certain agrarian villages for the exclusive use of Catholic and "respectable" migrants from

73. Written statement by Indian Seamen's Union (Bombay), RCLI Evidence, vol. I, part I (Bombay, Written Evidence), pp. 290-293; written statement by Mulchand M. Kripalani, Hon. General Secretary, Indian Seamen's Union (Karachi), ibid., p. 232; verbal testimony by Tarachand J. Lalwani and Mulchand M. Kripalani, Indian Seamen's Union (Karachi), ibid., vol. I, part 2 (Bombay, Oral Evidence), pp. 4If; verbal testimony by Mohammed Ibrahim Serang and P.G. Kanekar, Indian Seamen's Union (Bombay), ibid., p. 224. See also oral testimony by R. Liddle, Marine Superintendent, British Indian Steam Navigation Company, Calcutta, RCLI Evidence, vol. 5, part 2 (Bengal, Oral Evidence), p. 304.

74. Principal Officer, Mercantile Marine Dept, Calcutta District, to Secretary to the GoI, Dept of Commerce, 2 I July i93 I, NAI, Dept of Commerce, Mercantile Marine II, January i932, F. No. 32, M. II./3 I, s.nos. I-3, part B. See also ILOrep July I93 I, ILO Ci903/32, p. 80 (excerpt from The Pioneer, 2 July i931).

75. ILOrep Ci 1903 / I 19, pp. 34-35 (excerpt from The Labour Times, Madras, October 1938). See also Broeze, "The Muscles of Empire", pp. 66 and passim.

76. Mowat, Seafarers' Conditions in India and Pakistan, p. 79. 
that village. ${ }^{77}$ However, since the turn of the century they had also provided the organizational basis for a very early development of trade unions. The constitution of the Bombay Seamen's Union, at the time one of the strongest maritime unions in the port, prescribed as late as 1926 that members of its Committee had to be managers of "village clubs" and that only Goan Christians were acceptable as members. Before the major seamen's unions in Bombay opened up to all sections of ship workers in the late $1920 s,{ }^{78}$ resolutions were often concerned with preserving as a Goan domain all employment in the saloon departments of $\mathrm{P} \& \mathrm{O}$ and other shipping lines. ${ }^{79}$ When the British parliament decided in 1935 that tramp-shipping subsidies should be granted only for vessels employing "British subjects", even the Portuguese Embassy in London turned to the British Foreign Office in protest. ${ }^{80}$ Eventually, the Goan labour networks proved to be too well entrenched to be marginalized by such legislative measures. Even in the late I950s almost all stewards and cooks recruited in Bombay were Goan Christians. ${ }^{81}$

\section{SERANGS AND SURVEILLANCE}

If maritime labour networks contributed to structuring the access of the various communities of seafarers to the international maritime labour market, they were as much involved with regulating the individual mobility of seamen during their voyages. Detailed information regarding the labour process of lascars on British steamships is hard to come by, since many of the daily routines of surveillance and command, being delegated to Indian serangs, were conducted in languages British officers and engineers could not follow and consequently left few traces in their written documents. Further research is required in this field, but the evidence presently available suggests that the "informal" social relations between

77. The only systematic and unfortunately unpublished study of these "village clubs" is Baptista, "The 'Coor' System".

78. Verbal testimony by J.P. Lobo and Patrick DeSa, Bombay Seamen's Union, RCLI Evidence, vol. I, part 2 (Bombay, Oral Evidence), pp. 227-232; A. Colaco (ed.), A History of the Seamen's Union Bombay (Bombay, I955), pp. I 5-20, 70f. See also Ahuja, "Networks of Subordination"; Broeze, "The Muscles of Empire", p. 56.

79. See for example "The humble petition of the members of the Goa Portuguese Seamen's Club, the Portuguese Seafarers' Union and the Asiatic Seamen's (Saloon Crew) Union" to Sir G.A. Lloyd, Governor of Bombay, 23 July i 920, OIOC, BoMP, IOR/P/I0793, A273-274.

80. OIOC, Economic \& Overseas Department Collections, Seamen (1925-I $94 \mathrm{I}$ ), IOR/L/E/9/ 955. See also Balachandran, "Conflicts in the International Maritime Labour Market", pp. $89 f$. 81. Seamen's Employment Office, Bombay, No. of Seamen on Articles as on I sth May 1956, NMML, M.A. Master Papers, I. Subject Files, E. National Committees and Commissions, file 867; C.P. Shrivastava, National Board of Seafarers, to ?, dated I 4 July i 956 [sic, probably 1957], ibid., B. Shipping, file 482. 
serangs and lascars augmented the various legal techniques of limiting the incidence of "desertion" we have so far looked at.

The serang was no doubt an ambiguous social type, combining the features of crimp and patron, of foreman and subcontractor. He was his employer's agent, and spokesman for the crew, a moneylender, and organizer of the village clubs and trade unions. ${ }^{82}$ The ambiguous social position of these middlemen was also revealed in their role in regulating the lascars' spatial mobility. As has already been mentioned, serangs could be involved in extending their networks into the hinterlands of Britain and other metropolitan countries. ${ }^{8} 3$ Yet any serang who wished to stay in merchant shipping and hold continuous engagements strove to develop permanent links to a certain shipping company, to a particular shipmaster or chief engineer. That was possible since employers, from the I920s, apparently undertook greater efforts to regularize the labour relations of a skilled core of their crews and to foster a cadre of serangs who were well acquainted with the peculiarities of the labour process on their ships and had a reputation for being able to control their men, make them work, and prevent them from absconding in metropolitan ports. ${ }^{84}$

However, if colonial officials and spokesmen for the shipping industry asserted that crews "fell to pieces in a few days" and turned into "unwieldy indisciplined mobs" without the leadership of a powerful serang, some caution is in order. Balachandran has argued with some reason that these circles systematically overstated the community bonds of lascar crews and the power of the serang, which until the I940s enabled them successfully to legitimize a pseudo-traditional recruitment method, based on a complex system of mostly informal payments (or "bribes"), that offered considerable cost advantages to employers but

82. See G. Balachandran, "Searching for the Sardar: the State, Precapitalist Institutions, and Human Agency in the Maritime Labour Market", in Burton Stein and Sanjay Subrahmanyam (eds), Institutions and Economic Change in South Asia (Delhi, I996), pp. 216-220; Ahuja, "Networks of Subordination".

83. See above, in the section "Competing Labour Networks".

84. The British India Steam Navigation Co., by far the largest recruiter in Calcutta, manned I 27 ships in this port in $1929 / 30$, for which purpose they kept a register of 226 deck serangs, 200 firemen serangs, 782 sukhanis (helmsmen) and 200 butlers (foremen in the saloon department) who were given preference in engagement. As every ship required one foreman of each category and four helmsmen, the ratio between the registered and the employed was less than 2:I. Moreover, it was stated that no serangs had been added to the register for six or seven years, except when the necessity of immediate replacement occurred. The preference for fairly regular employment patterns with regard to these categories of seamen was also expressed in the payment of a pension or gratuity to serangs who had been in the company's service for twentyfive years. Oral testimony by R. Liddle, Marine Superintendent, British Indian Steam Navigation Company, Calcutta, RCLI Evidence, vol. 5, part 2 (Bengal, Oral Evidence), pp. 297-303. For further evidence of the tendency towards (partial) regularization of the maritime workforce see my "Die 'Lenksamkeit' des 'Lascars'”. 
was increasingly unpopular and contested by the seamen and even the serangs. ${ }^{85}$

Before the I950s, however, bonds of kinship and locality did usually connect at least the core of a crew to their respective serangs, whose recommendations on recruitment were usually accepted by the shipmaster. Crews were likely to become more heterogeneous in periods of great demand for maritime labour power, especially during the two World Wars. Community bonds might have been somewhat less pervasive in Calcutta than in Bombay, though the available evidence suggests - pace Balachandran - that the networks of Sylheti firemen, who worked the engine rooms of most steamers manned in Calcutta, were rather closely meshed. ${ }^{86}$ Even when the boatswain was not a family or village elder, most seamen needed credit to be able to discharge the various extra-legal fees that had to be paid to various middlemen before they received their agreement, and for this many of them had to turn to a serang too, or to a bariwallah, as boarding-house owners were called in Calcutta. These creditors frequently, though not always, came from the same or a neighbouring locality and lascars seem to have been unable in many cases to discharge their full debts even after receiving an advance on signing their articles. ${ }^{87}$

85. Written Statement by R. Liddle, Marine Superintendent, British Indian Steam Navigation Company, Calcutta, RCLI Evidence, vol. 5, part I (Bengal, Written Evidence), pp. 363; Oral testimony by H.F. Darvell, Shipping Master Calcutta, ibid., vol. 5, part 2 (Bengal, Oral Evidence), pp. 277, 298; Report of the Sub-Committee Appointed by the Owners to Consider Government of India Memoranda Relating to Conditions of Employment of Indian Seamen (not dated, c.1946); NMML, M.A. Master Papers, I. subject Files, E. National Committees and Commissions, file 786; see also [L.W. Balcombe,] Calcutta Liners Conference (Crews) to E.S. Krishnamoorthy, GoI, Dept of Commerce, ig February 1946 (confidential letter), ibid. See also Balachandran, "Recruitment and Control of Indian Seamen".

86. See Report of the Seamen's Recruitment Committee (Clow Committee), OIOC, BeMP, IOR/P/I I I78, A I (December I922), folio 3. The Clow Committee here opined (possibly under trade-union influence) that community bonds were of minor importance in Calcutta ("no close attachment between the serang and his crew"). For a concurrent opinion of a trade unionist and social reformer see also Kanekar, Seamen in Bombay, p. 29. Balachandran seems to accept this view to a certain extent ("Recruitment and Control of Indian Seamen", pp. I 2f., I 8; "Circulation through Seafaring”, pp. I०8-I I I, and personal communication with the author). However, life accounts collected by Adams (Across Seven Seas: Nawab Ali, p. 72, Haji Shirajul Islam, pp. 95f.; Abdul Malik, p. I I ; Haji Kona Miah, pp. I28-ı 30, Shah Abdul Majid Qureishi, pp. I46, I48; Abdul Wahab, p. 209), memories of former Sylheti seamen as presented by Choudhury (The Roots and Tales, pp. 35-43,53-56, and passim) and Gardner's fieldwork in Sylhet (Global Migrants, Local Lives, pp. 4I, 79f.) suggest a qualification of this assessment, which was also refuted by other officials and most eloquently by the Calcutta Shipping Master: H.F. Darvell to GoBe, Maritime Dept, I7 March I925, NAI, Dept of Commerce, Shipping, October 1927, file I04-S.(4), s.nos. I-6, part A (confidential), pp. 5f. See also Maritime Labour Advisory Committee, Memorandum on Recruitment of Indian Seamen, 9 April 1947, p. 3, NMML, M.A. Master Papers, I. subject files, F. International Committees and Commissions, file 9r6.

87. Oral Testimony by H.F. Darvell, Shipping Master Calcutta, RCLI Evidence, vol. 5, part 2 (Bengal, Oral Evidence), p. 270; Desai, Maritime Labour in India, pp. 44-48. 
Hence, bonds of community were backed up (in Calcutta even more than in Bombay) $)^{88}$ by bonds of debt, and this combination, together with the legal provisions of the "lascar agreements", created considerable disciplinary power for the serang on board ship. This power did not remain unchallenged and there were probably numerous instances when lascars clashed with serangs, who often acted in concert with ships' officers over the payment of informal commissions. Such conflicts usually remained unrecorded as most of them were resolved or suppressed informally on board ship. ${ }^{89}$ Some, however, came to such a head that they were noticed by state authorities. One such incident occurred in Salford in January 1920, when the greater part of the stokers of the SS Shanghai refused to make payments the serang had tried to enforce and insisted on being discharged. The owners saw no other way to solve the conflict than to transfer "the Serang and four of his relatives" to a different ship from the rest of the firemen. $9^{\circ}$

The refusal or inability of a lascar to pay the share of his wages the serang expected from him could thus lead to extremely tense relations on board ship. Under the dual necessity of fulfilling his own financial obligations and of maintaining his authority, the serang could not afford to permit non-payment. For the same compelling reason, he could not allow defaulting debtors to desert the ship, even laying aside the necessity of his maintaining his reputation with the employers as an efficient supervisor. Lascars, therefore, faced not just the formal power of the law, but also the informal might of the serang when they asserted their freedom of movement. If they came from the same village as their foreman, they had to consider, moreover, that he would hold their families responsible for their debts.

Interviews with veteran lascars, conducted by Caroline Adams in the East End of London in the early I980s, permit rare glimpses into the

88. Report of the Seamen's Recruitment Committee (Clow Committee), Appendix B: Report on the Preliminary Inquiry in Calcutta, NAI, Dept of Commerce, Lascar Seamen, August I922, s.nos. I-7, part A, pp. $37-38$.

89. However, the Calcutta Shipping Master put on record that in the year after the creation of his office, I 1925 , at least ten complaints had been received by his office from seamen every week, most of which had been directed against serangs, but that complaints had been much less in the following years. Oral testimony by H.F. Darvell, Shipping Master Calcutta, RCLI Evidence, vol. 5, part 2 (Bengal, Oral Evidence), pp. $267 \mathrm{f}$. See also oral testimony by R. Liddle, Marine Superintendent, British Indian Steam Navigation Company, Calcutta, RCLI Evidence, vol. 5, part 2 (Bengal, Oral Evidence), p. 279.

90. NAI, Dept of Commerce, Lascar Seamen, May i921, s.nos. 156-157, Filed. For lascarserang conflicts over payments see also F.S. Purnett, Chief Collector of Customs in Sind and Shipping Master Karachi, to Commissioner of Sind, 2 I February r9 13, OIOC, BoMP, IOR/P/ 9342, A 2 I 2; R.H.H. Hopkins, Shipping Master Bombay, to Secretary to GoBo, Marine Dept, 29 March I9I3, ibid., A2 I3-2 I4; Indian Seamen's Union, Resolution on the Pending Grievances of the Indian Seamen, 3 I August 1943, NMML, M.A. Master Papers, I. Subject Files, A. Scindia Steam Navigation Company, file iso. 
ensuing informal restraints on the mobility of South Asian seamen. They recalled serangs and watchmen sharply watching and preventing them from jumping ship, and remembered warnings that the serang would do "afraiding things" to deserters who were caught. One former seaman reported that his serang had been reluctant to hire the son of a "respectable" family, considering these prone to desertion, and had, therefore, taken a "vow" from his uncle to ensure he did not jump ship. ${ }^{91}$ Once again, the serang's power to prevent desertion was by no means absolute: desertion was rare in western ports, but in Calcutta almost $\mathrm{I}, 000$ or about 2 per cent of all engaged Indian seamen "deserted and failed to join their vessels" during some years. ${ }^{92}$ Yet that rate was apparently perceived by shipping interests as an indication of a high level of discipline.

The life accounts collected by Adams also disclose a strong feeling of empowerment among many of the former lascars. Seafaring had opened up the world to them; they were proud of the greater mobility they had achieved in comparison with their co-villagers and were unwilling to give that up. ${ }^{93}$ Yet mobility and containment simultaneously shaped the everyday lives of lascars on their voyages around the world and both the silences and the explicit statements of their accounts reflect this contradiction. Very strikingly, the narrators hardly ever refer to everyday life on board ship and confine themselves to recounting at length their onshore experiences in South Asia, Britain, and elsewhere. Statements like "I didn't like the ship because it was like a prison" give an inkling as to why this was so. 94

In colonial records there is a remarkable recurrence of the theme of lascar suicides, especially among firemen; that may be interpreted, too, as a hint at the strong sense of confinement that could emerge on board spatially, as well as socially, insulated steel vessels. Hence, the British Consul in Port Said stated in 1904 that fifteen suicides of lascars had been reported to him within the last two years, and he suspected that conflicts with serangs about the payment of "fees" were at the bottom of them. "In theory", Cameron reasoned, the lascar,

[...] can go on shore at the next port and complain to the Shipping Master; but, if practically he is a prisoner on board, it is possible that the man reviewing the hopelessness of his position may find the only solution in jumping overboard,

9r. Haji Shirajul Islam's account, in Adams, Across the Seven Seas, p. 96; Shah Abdul Majid Kureishi's account, ibid., p. I48.

92. Annual Report of the Calcutta Shipping Office for I9I 2-I9I3, OIOC, BeMP, IOR/P/9I I, A24; Annual Report of the Calcutta Shipping Office for 1913-1914, OIOC, BeMP, IOR/P/ 9385, A4I. But see also the considerably lower figure ( 383 or 0.9 per cent) in Annual Report of the Calcutta Shipping Office for I92 I-22, OIOC, BeMP, IOR/P/i i 178, A6.

93. Adams, Across Seven Seas, p. I4; Nawab Ali's account, ibid., p. 69; Shah Abdul Majid Kureishi's account, ibid., pp. I45f.

94. Nawab Ali's account, ibid., p. 79. 
whether to commit suicide on the high seas or to take his chance of reaching the shore of the Suez Canal.95

In the early I930s, the frequency of unnatural deaths among lascars during sea voyages became the object of (largely fruitless) investigations on the part of the Government of India. ${ }^{96}$ And even German shipping authorities noticed an unusual frequency of suicides of "coloured" trimmers and stokers in the early years of the twentieth century. ${ }^{97}$

\section{POSTSCRIPT AND CONCLUSIONS}

The first decade of Indian independence saw major changes in the scenario of maritime labour regulation, though the British shipping industry remained the most important employer of South Asian seamen by far. In fact, the old "informal" recruitment system that had shown its first cracks in the I920s, and had been further undermined under the pressure of increasing labour demand during World War II, was now more systematically replaced by corporatist modes of controlling the supply and reproduction of labour - a process I have discussed elsewhere..$^{8}$

As for the regulation of maritime labour mobility, the partition of India and economic developments in Britain affected many of the patterns that had emerged in the era of steam shipping. Areas like the North-West Frontier Province, West Punjab, Sylhet, Chittagong, or Noakhali, which so far had provided a large number of seamen, were all of a sudden separated from Calcutta and Bombay, the two major ports of recruitment, by a contested international border. Yet the effects of partition on maritime labour migration were not identical for the western and eastern

95. W.H. Howell, Board of Trade, Marine Dept, to Under-Secretary of State for India, I 2 December 1904, OIOC, BoMP, IOR/P/7I 91, A 228; D.A. Cameron, British Consul in Port Said, to Board of Trade, Marine Dept, 3 November 1904, ibid., A229. However, not only serangs, but also engineers and other "white" officers could make a seaman's life so difficult as to induce him to put an end to it. See for example A. Challis, London City Mission, to Board of Trade, I 3 January I9I3, OIOC, BoMP, IOR/P/9083, A469.

96. See for instance NAI, Dept of Commerce, Merchant Marine II, January 1932, F. No. 54-M. $\mathrm{II} / 3$ I, S. Nos. I-42, part B. Various other files regarding "death on board ship" can be found in the 1932 and 1933 indices of this series of records, though several were apparently "not transferred" to the NAI. See also oral testimony by H.F. Darvell, Shipping Master Calcutta, RCLI Evidence, vol. 5, part 2 (Bengal, Oral Evidence), p. 279.

97. The shipping authority of Bremen, home base of the Hansa DFG (the largest German employer of Indian seamen), noted that 6I per cent of the 106 trimmers and stokers who committed suicide between I90 I and I9I 2 were "coloured". See Hartmut Rübner, "Lebens-, Arbeits- und gewerkschaftliche Organisationsbedingungen chinesischer Seeleute in der deutschen Handelsflotte. Der maritime Aspekt der Ausländersbeschäftigung vom Kaiserreich bis in den NS-Staat", Internationale wissenschaftliche Korrespondenz zur Geschichte der deutschen Arbeiterbewegung, 4 (1997), pp. I-4I, I9.

98. Ahuja, "Die 'Lenksamkeit' des 'Lascars”. 
regions of the subcontinent. In Bombay, Punjabis and Pashtuns had apparently all but disappeared from the lists of the newly founded Seamen's Employment Office by the second half of the I950s, while the presence of seamen from the shores of South India became more noticeable. ${ }^{99}$ In Calcutta, the shift brought about by partition was more gradual: of the 19,000 seamen who signed on in 1955, more than 10,000 were East Pakistanis; even today Bangladeshis have a certain presence among the crews of Indian merchant ships. ${ }^{100}$

However, younger seamen tended to be Indian citizens and there were organized efforts by a paramilitary group called the West Bengal National Volunteer Corps to give each month fifty Indian youths, most of them without any maritime background, a very basic training as firemen after they had been drilled in military discipline and patriotism for several weeks. ${ }^{\text {IOI }}$ For reasons deserving further exploration (including the introduction of a passport and visa system in 1952), cross-border migration of maritime workers appears to have lost by and by much of its attraction or practicability (though it did not disappear completely), while hopes to create job alternatives by enticing shipping away from Calcutta to the East Pakistani ports of Chalna and Chittagong did not materialize. ${ }^{102}$

Of the older networks, only those linking Goan Catholics and the Konkani Muslims to Bombay appear to have survived as maritime labour networks. ${ }^{103}$ That does not mean the other informal infrastructures of incorporation simply disintegrated. Contrary to current conceptualizations ascribing an inherent impermanency to "informal" networks as opposed to an assumed greater durability of "formal", state-based institutional structures, several South Asian maritime labour networks showed a remarkable capacity for endurance and resilience. Several of them bypassed the new restrictions imposed on them by the Indo-Pakistan

99. C.P. Shrivastava, National Board of Seafarers, to ??, dated I 4 July 1956 [sic, probably 1957], NMML, M.A. Master Papers, I. Subject Files, B. Shipping, file 482.

Iо०. National Welfare Board for Seafarers, Special Subcommittee for Welfare in Ports, Proceedings, Examination of K.C. Ray, 8 August 1956, NMML, M.A. Master Papers, I. Subject Files, E. National Committees and Commissions, file 863; interview with Abdulgani Y. Serang, General Secretary, National Union of Seafarers of India, Io March 2003.

I0I. National Welfare Board for Seafarers, Special Subcommittee for Welfare in Ports, Proceedings, Visit to TS Bhadra and Examination of Captain Mody, 8 August 1956, ibid.

102. Adams, Across Seven Seas, p. 61; Choudhury, The Roots and Tales, pp. 86-90; see also Mowat, Seafarers' Conditions in India and Pakistan, pp. 8I-83.

I03. Seamen's Employment Office, Bombay, No. of Seamen on Articles as on is May 1956, NMML, M.A. Master Papers, I. Subject Files, E. National Committees and Commissions, file 867; interview with Abdulgani Y. Serang, General Secretary, National Union of Seafarers of India, Io March 2003 (who stressed the continuity of employment from Goa, while that from the Konkan had somewhat declined); interview with Joseph Mascarenhas, former Chief steward and third-generation seaman from Concolim (Goa), I3 March 2003 (who mentioned for example that the seamen's villages of Assolna, Velim, and Concolim still maintained an association of clubs in Mumbai with more than I०,000 members). 
border by turning into networks of large-scale international labour migration. In this process, "informal" infrastructures were once more intertwined with "formal" political and legal arrangements.

One of the most important leaders of the pre-Independence seamen's unions, Aftab Ali, a Sylheti who had been a lascar himself, became a prominent politician in East Pakistan. In the I950s and I960s, he used his influence to arrange for the legal immigration of thousands of former seamen (as well as other Sylhetis) to the United Kingdom, where industry had a demand for large numbers of immigrant workers. Consequently, London's Sylheti immigrants, a small group of a few hundred at the end of World War II, emerged in the course of the I960s as a major migrant community comprising about 35,000 people. ${ }^{104}$ The "voucher system", which permitted the immigration of a certain quota between 1962 and 1966, was also appropriated by another former maritime labour network, that of the Mirpuris, to transform itself into an infrastructure of migration. ${ }^{\text {105 }}$

The objective of this essay was, however, not merely to reconstruct the pattern of spatial mobility or immobility of South Asian seamen, but also to test the validity of a set of more general hypotheses in this specific case. It started from the understanding that the notion of a "labour market" is merely an abstraction "summarizing complex human arrangements", ${ }^{106}$ which need to be reconstructed historically. Moreover, it was assumed that such complex arrangements cannot be reduced to "purely economic" relations, as they necessarily involve political and social forms of regulation. Ethnic segmentation of a labour market is thus not merely a simple derivative of pre-existing differentials in the price of labour power between metropolitan and colonial regions, ${ }^{107}$ but also the result of ongoing formal, public, and state-based as well as informal, private, and network-based regulatory activities. ${ }^{108}$

Thus, in the case under review, wage differentials between European "seamen" and Indian "lascars" were apparently less pronounced before the emergence of a large-scale global market for steamship labour; ethnic segmentation was the concomitant of this process of spatial integration rather than the residue of earlier differentials between weakly linked

104. Adams, Across Seven Seas, pp. 58, 6I-66; Gardner, Global Migrants, Local Lives, pp. 43$47,56 f$.

I05. Ballard, "The Context and Consequences of Migration", p. I25.

I06. Wolf, "Incorporation and Identity", p. 366.

107. For this view see Edna Bonacich, "The Past, Present, and Future of Split Labour Market Theory", Research in Race and Ethnic Relations, I (1979), pp. 17-64, I9 and passim.

I08. However, the distinction between "informal" and "formal" regulation is understood as an auxiliary tool for analytical purposes, while in reality both types would often merge into each other (as for instance in the case of trade unions, which were, as we have shown, often based on informal networks but aspired to legal recognition). 
regions. Moreover, neither the exclusion of one of the racially defined groups nor an ethnic division of labour ensued from the wage differential between "seamen" and "lascars": 109 Europeans and South Asians continued to do the same work on deck, in engine rooms and saloons, though not side by side on the same ships.

Such permanency of ethnic segmentation in the market for steamship labour is the more striking if we consider the seamen's inordinately high level of spatial mobility, which suggests a tendency towards an equalization of labour relations. The phenomenon of permanent segmentation can be explained, however, by taking into account the interacting levels of political domination and social power that reduced the actual ability of the lascars to appropriate to their own purposes the movements of their workplaces between low-pay and high-pay regions. ${ }^{\text {I0 }}$ Such an explanation would have four constituents.

First, the very uneven access to resources of state power in both Britain and India available to the highly monopolistic British shipping industry on the one hand, and to British as well as Asian and African maritime workers on the other, which was reflected in the consistent racial differentiation of maritime labour law. Secondly, the equally uneven access to resources of state power available to metropolitan working classes on the one hand and to colonial labourers on the other, in combination with concerns about political stability on the part of the metropolitan ruling bloc, which was reflected in restrictive immigration policies. Thirdly, the spatial unevenness of processes of labour market integration under capitalism, which was reflected in the emergence of closely meshed and mainly informal maritime networks in some regions - networks that were ethnic in form but social in content and had the ability to control access to this labour market and exclude competitors from other regions lacking networks of equal strength. And fourthly, the uneven distribution of resources of informal power between the social interests constituting these maritime labour networks, which was reflected in the fact that they functioned predominantly (though not consistently) as informal devices for further limiting the access of Indian seamen to higher-pay and superior-rights segments of the labour market.

I09. These are the alternative "resolutions" of the problem of "split labour markets" suggested by Edna Bonacich, ibid., p. I8.

I IO. For a study that stresses the importance of access to state power in conflicts between social groups involved with "split labour markets" see Yoav Peled and Gershon Shafir, "Split Labor Market and the State: The Effect of Modernization on Jewish Industrial Workers in Tsarist Russia", American Journal of Sociology, 92 (1987), pp. 1435-1466. For the contribution of (predominantly informal) social networks to the ethnification of labour market segmentations see Wolf, "Incorporation and Identity", pp. 366f. By introducing the concept of "scenarios of regulation", I try to come to grips with the interconnectedness of these seemingly separate practices of political and social power. 
This scenario of regulation was subject to historical change. The end of colonial rule and the emergence of an Indian shipping industry, the rise and demise of post-colonial corporatism, the coming of container shipping and passenger aviation, the shift of major metropolitan shipping lines to other Asian labour networks: all were major developments transforming the position of South Asian seamen in the international maritime labour market. However, the regulation of the Indian seaman's freedom of movement continues to be an issue of conflict. When in March 2003 this author talked to Abdulgani Serang, the General Secretary of the National Union of Seafarers of India, he maintained that the employment situation had deteriorated considerably since II September 200I, when Indian seamen were barred from US ports. Even in the era of so-called "globalization", incorporation and mobility share a cabin with exclusion and containment. 